\title{
Treatment with licofelone prevents abnormal subchondral bone cell metabolism in experimental dog osteoarthritis
}

\author{
D Lajeunesse, J Martel-Pelletier, J C Fernandes, S Laufer, J-P Pelletier
}

Ann Rheum Dis 2004;63:78-83. doi: 10.1136/ard.2002.003624

See end of article for authors' affiliations

\section{Correspondence to:} Dr D Lajeunesse, Unité de recherche en Arthrose, CHUM, Hôpital NotreDame, 1560, rue Sherbrooke Est, Montréal, Québec, H2L 4M1 Canada;

lajeunda@jonction.net

Accepted 3 February 2003

\begin{abstract}
Objectives: To determine if treatment with licofelone, a combined 5-lipoxygenase and cyclo-oxygenase inhibitor, in vivo in experimental dog osteoarthritis can modify bone cell metabolism in long term in vitro subchondral osteoblast cell cultures (Ob).

Methods: Group 1 received sectioning of the anterior cruciate ligament $(A C L)$ of the right knee with no active treatment (placebo group). Groups 2 and 3 received sectioning of the $\mathrm{ACL}$ of the right knee, and were given licofelone ( 2.5 or $5.0 \mathrm{mg} / \mathrm{kg}$ daily by mouth, respectively) for eight weeks beginning the day after surgery. Primary $\mathrm{Ob}$ were prepared from the subchondral bone plate. Levels of phenotypic markers (alkaline phosphatase activity, osteocalcin release), and urokinase plasminogen activator (UPA) and insulin-like growth factor-1 (IGF-I) levels, were evaluated in each group. Lastly, prostaglandin $E_{2}\left(P_{G} E_{2}\right)$ and leucotriene $\mathrm{B}_{4}$ levels were evaluated.

Results: No significant differences in alkaline phosphatase activity or osteocalcin release from Ob between the three groups, under either basal or $1,25(\mathrm{OH})_{2} \mathrm{D}_{3}$ induction were seen. In contrast, treatment with licofelone reduced uPA and IGF-I levels in Ob. PGE 2 levels, which were still raised in the placebo group, were decreased sharply by licofelone. A relationship was found between licofelone treatment and either the reduction in the size of lesions on tibial plateaus or the levels of UPA, IGF-I, or PGE 2 .

Conclusions: Licofelone treatment prevents and/or delays the abnormal metabolism of subchondral osteoblasts in this model. Licofelone reduced $\mathrm{PGE}_{2}$ levels after long term $\mathrm{Ob}$, suggesting that the reduction in UPA and IGF-I levels is linked, at least in part, to this reduction.
\end{abstract}

experimental OA dog model. ${ }^{15}$ Several factors produced by osteoblasts might potentially affect cartilage chondrocytes. ${ }^{21-24}$ In particular, the local bone tissue production of insulin-like growth factor-I (IGF-I), urokinase plasminogen activator (uPA), and prostaglandin $\mathrm{E}_{2}\left(\mathrm{PGE}_{2}\right)$ may play a part in the attempt of the cartilage to promote the formation of a new extracellular cartilage matrix such as that seen in OA. Cytokines/growth factors/prostaglandins produced by subchondral bone cells may seep through the bonecartilage interface to stimulate cartilage breakdown. Indeed, increasing evidence indicates the presence of channels and fissures between cartilage and bone that might provide a route for signals between these two tissues. ${ }^{25-27}$

The experimental OA dog model is a reliable model that allows the study of early changes of the disease as well as several pathophysiological pathways. ${ }^{11} 2829$ Reports show that in this model of OA the subchondral bone is the site of important morphological changes. ${ }^{12-15}$ As early as two to three months after surgery, the subchondral bone plate is osteopenic, and this phenomenon reversed with the appearance of bone sclerosis between 18 and 54 months after the anterior cruciate ligament (ACL)..$^{12} 15$ The development of osteopenia was also confirmed by histomorphometric studies in this model. ${ }^{11} 12{ }^{14}{ }^{15}$ Our own previous studies with primary
Abbreviations: $\mathrm{ACL}$, anterior cruciate ligament; $\mathrm{COX}$, cyclo- oxygenase; DMEM, Dulbecco's modified Eagle's medium; ELISA, enzyme linked immunosorbent assay; FBS, fetal bovine serum; IGF-I, insulin-like growth factor-I; ITS, insulin-transferrin-selenium; 5-LO, 5-lipoxygenase; $\mathrm{LTB}_{4}$, leucotriene $\mathrm{B}_{4}, \mathrm{NSAID}$, non-steroidal anti- inflammatory drug; $O A$, osteoarthritis; $O b$, osteoblast cell cultures; $1,25(\mathrm{OH})_{2} \mathrm{D}_{3}, 1,25$-dihydroxyvitamin $\mathrm{D} ; \mathrm{PGE}_{2}$, prostaglandin $\mathrm{E}_{2}$; TGF $\beta$, transforming growth factor $\beta$; UPA, urokinase plasminogen activator 
subchondral osteoblasts from an experimental OA dog model showed raised UPA and IGF-I levels, but did not present altered alkaline phosphatase activity or osteocalcin release. ${ }^{15}$

Licofelone (previously named ML-3000), a new antiinflammatory drug with combined 5-lipoxygenase (5-LO) and cyclo-oxygenase (COX)-I/COX-II inhibitory activity, has been previously shown to reduce the development of cartilage lesions in experimental dog OA. ${ }^{30}$ Here we evaluated the long term effects of treatments of experimental dog OA with licofelone on the synthetic abilities of isolated subchondral osteoblasts from these animals.

\section{METHODS}

\section{Experimental groups}

Tibial plateaus obtained from dogs from different experimental groups included in our previous study were used. ${ }^{30}$ In short, 21 adult crossbred dogs 2-3 years old, weighing 20$25 \mathrm{~kg}$ each, were used in this study. Surgical sectioning of the ACL of the right knee was performed on 21 dogs through a stab wound, as previously described. ${ }^{29-32}$ Before surgery, the animals were anaesthetised intravenously with pentobarbital sodium $(25 \mathrm{mg} / \mathrm{kg})$ and intubated. After surgery, the dogs were kept in animal care facilities for one week then sent to a housing farm. Dogs were housed in a large pen and were exercised under supervision to ensure that they were bearing weight on the operated knee as approved by the Institutional Committee for Animal Protection of our institution.

These dogs were randomly separated into three groups of seven: group 1, dogs with OA that received placebo (encapsulated methylcellulose); group 2, dogs with OA given encapsulated licofelone $(2.5 \mathrm{mg} / \mathrm{kg}$ daily by mouth) (Merckle GmbH, Ulm, Germany); group 3, dogs with OA given encapsulated licofelone $(5.0 \mathrm{mg} / \mathrm{kg}$ daily by mouth). Treatments began the day after surgery. These doses were selected based on the doses of the drug given to patients for the treatment of symptomatic OA. Licofelone was given twice daily ( $8 \mathrm{am}$ and $4 \mathrm{pm}$ ) with food at the total daily dose of 2.5 and $5.0 \mathrm{mg} / \mathrm{kg}$. All dogs were killed eight weeks after surgery. Gross morphological changes in these animals, including the presence of osteophyte formation and cartilage lesions, were reported previously. ${ }^{30}$

\section{Primary bone cell cultures}

The specimens obtained from the dogs with OA represented moderate OA according to macroscopic criteria. Sections from the weightbearing areas of the subchondral bone plate of tibial plateaus were processed as previously described. ${ }^{15}$ Briefly, specimens were obtained from plug explants of the tibial plateaus collected at an equivalent anatomical site. Both the overlying cartilage and the trabecular bone sections were removed under a magnifying microscope to ensure total removal of both tissues. The remaining subchondral bone plate was then cut into small pieces $\left(2 \mathrm{~mm}^{2}\right)$ before sequential digestion using $1 \mathrm{mg} / \mathrm{ml}$ of collagenase type I (Sigma-Aldrich Canada, Oakville, ON, Canada) in Ham's F12/Dulbecco's modified Eagle's medium (DMEM; Sigma) without serum, at $37^{\circ} \mathrm{C}$ for two periods of 30 minutes and, lastly, for 240 minutes. This removed both adherent and remaining bone marrow cells from the subchondral bone pieces.

These bone pieces were then washed extensively with Ham's F12/DMEM media without serum containing 5\% PenStrep before being cultured in Bigger, Gwatkin, Jackson (BGJ; Sigma) medium containing 20\% fetal bovine serum (FBS; Wisent, St-Bruno, Quebec, Canada). This medium was replaced every two days until cells appeared in Petri dishes. At this point, it was replaced by the same medium containing $10 \%$ FBS. At confluence (days 14-18), cells were passaged once at a ratio of 25000 cells $/ \mathrm{cm}^{2}$ and grown in 24 well plates
(Falcon, Lincoln Park, NJ, USA) for five days before assay. Cells prepared under these conditions show an osteoblastlike phenotype. ${ }^{15} 33{ }^{34}$ Cells from dogs with OA treated or not with licofelone grew at similar rates (not shown), indicating that cell viability was not affected by prior surgery or by treatment. Conditioning was performed for the last two days of culture, and two sets of experimental conditions were performed. Half of the cells were incubated in the presence or absence of $50 \mathrm{nM}$ 1,25-dihydroxyvitamin $\mathrm{D}\left(1,25(\mathrm{OH})_{2} \mathrm{D}_{3}\right.$; generous gift of Dr M Uskokovic, Roche, Nutley, NJ, USA) for maximal stimulation, in Ham's F12/DMEM containing 2\% charcoal-stripped FBS to determine alkaline phosphatase activity and osteocalcin release. The medium was collected at the end of the incubation and frozen before assay at $-80^{\circ} \mathrm{C}$. Cells were washed twice with phosphate buffered saline, $\mathrm{pH} 7.4$, and solubilised in alkaline phosphate buffer ( $100 \mathrm{mM}$ glycine, $1 \mathrm{mM} \mathrm{MgCl}_{2}, 1 \mathrm{mM} \mathrm{ZnCl} 2,1 \%$ Triton X100; $\mathrm{pH} 10.5)$ for 60 minutes with agitation at $4^{\circ} \mathrm{C}$. The second half of the cells were incubated for their last two days of culture with Ham's F12/DMEM media without FBS containing $1 \%$ insulin-transferrin-selenium mix (ITS; Sigma) and were used for the determination of uPA activity, and the determination of IGF-I and PGE 2 levels. Under these conditions cell viability is maintained, and previous studies have shown that osteoblasts can still respond to exogenous modulation. ${ }^{52324}$

\section{Determination of alkaline phosphatase activity and osteocalcin release}

Cell lysates from cells treated or not with $1,25(\mathrm{OH})_{2} \mathrm{D}_{3}$ were used for the determination of alkaline phosphatase activity as the release of $p$-nitrophenol hydrolysed from $p$-nitrophenyl phosphate $\left(12.5 \mathrm{mmol} / \mathrm{l}\right.$ final concentration) at $37^{\circ} \mathrm{C}$ for 30 minutes. Protein determination was performed by the bicinchoninic acid method on the same cell lysates. ${ }^{35}$ Osteocalcin release was measured in conditioned Ham's F12/ DMEM media ( $1: 1)$ prepared for the last two days of culture of osteoblasts treated or not with $1,25(\mathrm{OH})_{2} \mathrm{D}_{3}$. Nascent dog osteocalcin was determined by a specific radioimmunoassay (Biomedical Technologies, Stoughton, MA, USA). The detection limit of this assay is $0.5 \mathrm{ng} / \mathrm{ml}$, and $2 \%$ charcoal-stripped FBS contains $<0.1 \mathrm{ng} / \mathrm{ml}$ osteocalcin. Determinations were performed in triplicate for each assay.

\section{Determination of UPA activity, and of IGF-I, PGE 2 , and $\mathrm{LTB}_{4}$ levels}

UPA activity was determined by the procedure of Leprince et al. ${ }^{36}$ This assay determines the activity of uPA by the hydrolysis of the specific substrate DL-Val-Leu-Arg- $p$-nitroanilide (Sigma), which releases $p$-nitroaniline detectable at $405 \mathrm{~nm}$. IGF-I levels were determined by a high sensitivity enzyme linked immunosorbent assay (ELISA; Diagnostic Systems Laboratories, Webster, TX, USA) that does not cross react with insulin. Samples were treated according to the method described by Mohan et al ${ }^{37}$ to detect total IGF-I levels. Internal control studies were performed with the media alone containing $1 \%$ ITS, and values were below the limit of detection for IGF-I. PGE 2 and leucotriene $\mathrm{B}_{4}\left(\mathrm{LTB}_{4}\right)$ levels were determined by a highly specific EIA from Cayman Chemicals (Ann Arbor, MI). The limit of quantification was $15 \mathrm{pg} / \mathrm{ml}$ and $5 \mathrm{pg} / \mathrm{ml}$ respectively for $\mathrm{PGE}_{2}$ and $\mathrm{LTB}_{4}$. This ELISA is a very specific assay that does not cross react with related prostaglandins when tested at saturating concentrations. Determinations were performed in triplicate for each cell culture preparation.

\section{Statistical analysis}

Values are expressed as the mean (SEM). Statistical analysis was done with the Mann-Whitney $U$ test. Values of $p<0.05$ 
were considered significant. Only significant values were included in the figures.

\section{RESULTS}

\section{Macroscopic findings}

Macroscopic findings for these animals have been reported previously. ${ }^{30}$ In brief, osteophytes were seen in $93 \%$ of the condyles of the OA placebo treated group, and their mean (SEM) width was $4.50(0.66) \mathrm{mm}$. Osteophytes were still present in licofelone treated groups at $93 \%$ and $86 \%$ in the dogs treated with $2.5 \mathrm{mg} / \mathrm{kg} /$ day and $5.0 \mathrm{mg} / \mathrm{kg} / \mathrm{day}$, respectively and their widths were not statistically smaller in the licofelone treated groups (3.57 (0.56) and $3.86(0.66) \mathrm{mm}$, respectively). ${ }^{30}$ Cartilage lesions of moderately severe grade were seen in both condyles and plateaus, with more severe lesions on the plateaus. Licofelone reduced the size of lesions significantly on the plateaus of both groups by $39 \%$ and $64 \%$ in the 2.5 and $5.0 \mathrm{mg} / \mathrm{kg}$ /day groups, respectively $(\mathrm{p}<0.05$ and $\mathrm{p}<0.04$, respectively compared with the OA placebo treated group). ${ }^{30}$

\section{Phenotypic markers of osteoblasts}

Osteoblasts from all groups of dogs had normal microscopic appearance. The level of basal alkaline phosphatase activity in primary dog osteoblasts was not increased significantly in response to $1,25(\mathrm{OH})_{2} \mathrm{D}_{3}$ treatment (fig 1 ), a situation previously observed with dog osteoblasts. ${ }^{15}$ Licofelone failed to alter this activity under either basal or $1,25(\mathrm{OH})_{2} \mathrm{D}_{3}$ induction. In contrast, treatment with $1,25(\mathrm{OH})_{2} \mathrm{D}_{3}$ stimulated osteocalcin release from relatively low basal levels in all groups (fig 2); however, licofelone did not significantly alter osteocalcin release compared with placebo. There was a tendency for the $2.5 \mathrm{mg} / \mathrm{kg} /$ day group to show higher levels of $1,25(\mathrm{OH})_{2} \mathrm{D}_{3}$ induced osteocalcin release, but this failed to reach significance.

\section{Osteoblasts UPA activity, and IGF-I, PGE 2 , and LTB 4 levels}

We previously showed that uPA activity is already increased in osteoblast cell cultures $(\mathrm{Ob})$ from experimental dogs with

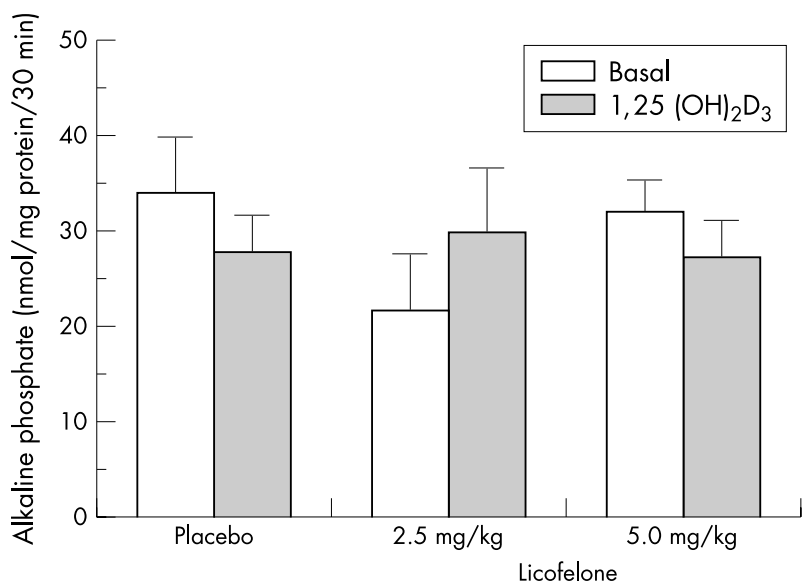

Figure 1 Evaluation of alkaline phosphatase activity of in vitro osteoblasts after in vivo treatment with placebo or with $2.5 \mathrm{mg} / \mathrm{kg}$ or $5.0 \mathrm{mg} / \mathrm{kg}$ licofelone daily for eight weeks of dogs with OA. Confluent primary osteoblasts were incubated for their last two days of culture with Ham's F12/DMEM containing $2 \%$ charcoal treated FBS in the presence or absence of $50 \mathrm{nM} 1,25(\mathrm{OH})_{2} \mathrm{D}_{3}$. Alkaline phosphatase activity was determined by the hydrolysis of $p$-nitrophenyl phosphate into $p$-nitrophenol. Values are the mean (SEM) of seven cell cultures for each experimental group. No statistical differences were seen between the groups.

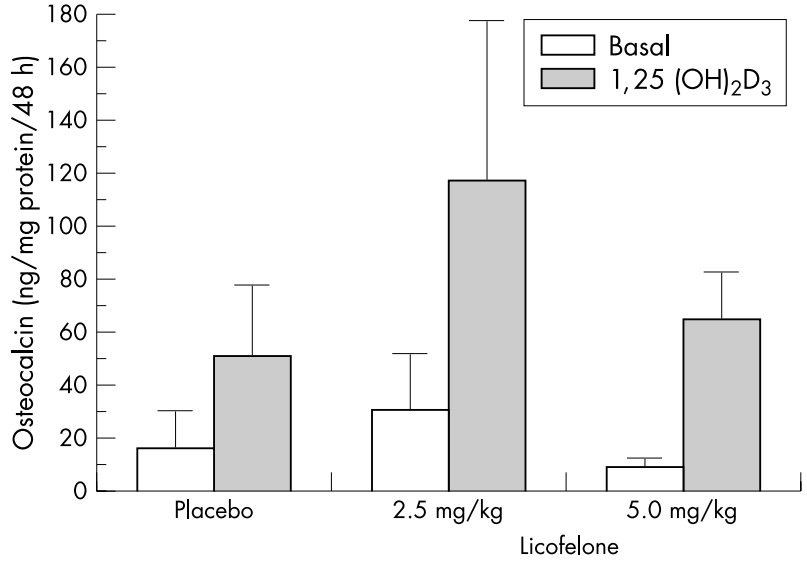

Figure 2 Evaluation of osteocalcin release of in vitro osteoblasts after in vivo treatment with placebo or with $2.5 \mathrm{mg} / \mathrm{kg}$ or $5.0 \mathrm{mg} / \mathrm{kg}$ licofelone daily for eight weeks of dogs with OA. Confluent primary osteoblasts were prepared with the same experimental protocol as in fig 1 . Osteocalcin release was determined on aliquots of conditioned media by radioimmunoassay. Values are the mean (SEM) of seven cell cultures for each group. No statistical differences were seen between the groups.

OA compared with controls. ${ }^{15}$ In vivo licofelone treatment was able to reduce this in vitro activity in long term culture of OA Ob by about $50 \%$ and $60 \%$ for the 2.5 and $5.0 \mathrm{mg} / \mathrm{kg} /$ day groups, respectively (fig 3 ). Likewise, licofelone reduced total IGF-I synthesis in these cells by $30 \%$ and $50 \%$ for the 2.5 and $5.0 / \mathrm{mg} / \mathrm{kg} /$ day groups, respectively (fig 4 ). $\mathrm{PGE}_{2}$ levels were still very high in the placebo group despite long term in vitro $\mathrm{Ob}$, and licofelone reduced these levels significantly. Indeed, both doses of licofelone also had a profound effect on $\mathrm{PGE}_{2}$ production, especially in the $2.5 \mathrm{mg} / \mathrm{kg} /$ day group where it reduced $\mathrm{PGE}_{2}$ production by about $80 \%$ (fig 5 ). In contrast with $\mathrm{PGE}_{2}, \mathrm{LTB}_{4}$ levels were very low in the placebo group (28.6 (2.6) $\mathrm{pg} / \mathrm{mg}$ protein) and remained unchanged in response to licofelone treatment $(25.9(10.2)$ and 39.4 (3.0) $\mathrm{pg} / \mathrm{mg}$ protein for the 2.5 and $5.0 \mathrm{mg} / \mathrm{kg} /$ day groups, respectively). The reduction in uPA activity, IGF-I, and $\mathrm{PGE}_{2}$ levels was paralleled by the reduction seen in the size of the lesions of the plateaus in these dogs (fig 6). Indeed, licofelone reduced the size of plateaus by about half in both groups; however, the difference between these two groups was not statistically significant.

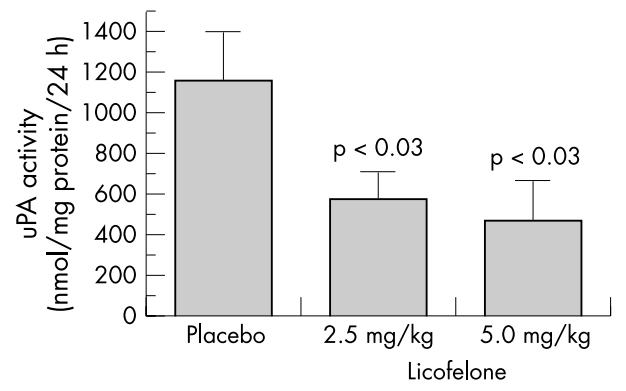

Figure 3 Evaluation of urokinase plasminogen activator (UPA) activity in dog osteoblasts. Dogs were treated with placebo or with $2.5 \mathrm{mg} / \mathrm{kg}$ or $5.0 \mathrm{mg} / \mathrm{kg}$ licofelone for eight weeks before the preparation of primary osteoblast cell cultures. Confluent primary dog osteoblasts were incubated for their last two days of culture in the presence of Ham's F12/ DMEM without serum containing 1\% ITS mix. UPA activity was determined on aliquots of conditioned media using a chromogenic substrate. Values are the mean (SEM) of seven cell cultures for each group. 


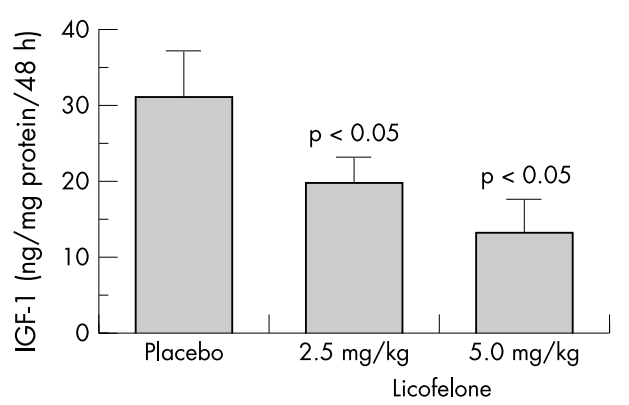

Figure 4 Evaluation of insulin-like growth factor-I (IGF-I) levels in dog osteoblasts. The same experimental protocol as in fig 3 was performed. IGF-I levels were determined by a selective ELISA. Values are the mean (SEM) of seven cell cultures for each group.

\section{DISCUSSION}

As we previously showed that licofelone reduced the progression of experimental OA in our dog model, ${ }^{30}$ we wanted to determine whether this new combined inhibitor of 5-LO and COX might influence osteoblasts from the subchondral bone plate and grown in in vitro culture. As this technical approach requires long term culture of these cells and we could expect a washout of the drug, it is noteworthy that licofelone could still exert an effect in vitro under these conditions. This indicates that either the drug itself has a long half life in vivo as well as in vitro, or that the effects it initiated in vivo in the bone tissue were carried over into in vitro experiments. This is similar to the observation we previously made in this same experimental OA dog model with another non-steroidal anti-inflammatory drug (NSAID), carprofen. ${ }^{15}$ Both studies suggest that osteoblasts are intimately involved in the development/progression of OA, and that any intervention that modifies abnormal bone cell metabolism under these conditions could contribute to preventing the onset or reducing the progression of OA. In this animal model of OA, morphological subchondral bone changes were observed consistent with altered bone remodelling. Indeed, the bone surface and trabecular width were reduced compared with normal dog bone tissues, whereas the number of osteoclasts per $\mathrm{mm}^{2}$ was raised in OA bone tissue compared with normal. Licofelone treatment of dogs with OA significantly improved all these measures (manuscript in preparation).

Because licofelone was very effective and is a combined inhibitor of 5-LO and COX, this raises the possibility that both pathways may be involved in the onset/progression of OA. This last hypothesis is reinforced by our recent observation that both $\mathrm{PGE}_{2}$ and $\mathrm{LTB}_{4}$ levels are raised in human OA subchondral osteoblasts, and that licofelone reduced the synthesis of both eicosanoids in in vitro experiments. ${ }^{23}$ Moreover, the observation that chronic reduction of $\mathrm{PGE}_{2}$ synthesis by COX-2 inhibition in human OA subchondral osteoblasts leads to increased $\mathrm{LTB}_{4}$ synthesis argues in favour of both pathways being involved in this process. ${ }^{23}$

Our study indicated that licofelone had no adverse effects on cell proliferation or differentiation of osteoblasts as it did not significantly modify either alkaline phosphatase activity or osteocalcin release. The lack of effect of $1,25(\mathrm{OH})_{2} \mathrm{D}_{3}$ on alkaline phosphatase activity is specific for dog osteoblasts as this activity is usually stimulated by $1,25(\mathrm{OH})_{2} \mathrm{D}_{3}$ treatments in other osteoblast-like cells. ${ }^{4} 53334$ We previously observed similar behaviour of dog osteoblasts in vitro. ${ }^{15}$ However, this situation is not related to a lack of response to $1,25(\mathrm{OH})_{2} \mathrm{D}_{3}$ because osteocalcin release, which is strictly dependent on $1,25(\mathrm{OH})_{2} \mathrm{D}_{3}$ induction in osteoblasts, ${ }^{38}$ was stimulated by vitamin $\mathrm{D}$ in this study.

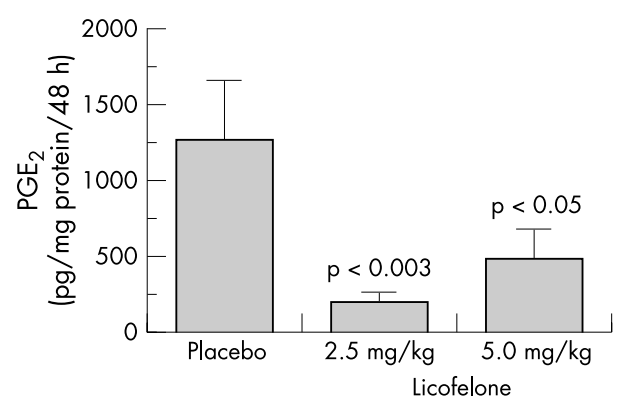

Figure 5 Evaluation of prostaglandin $\mathrm{E}_{2}\left(\mathrm{PGE}_{2}\right)$ levels in dog osteoblasts. The same experimental protocol as in fig 3 was performed. $\mathrm{PGE}_{2}$ was determined on aliquots by a selective ELISA. Values are the mean (SEM) of seven cell cultures for each group.

The fact that licofelone did not modify any of these activities indicates that this drug does not modify the osteoblast phenotype, a situation also observed with another NSAID, carprofen. ${ }^{15}$ Indeed, neither alkaline phosphatase activity nor osteocalcin release from OA dog osteoblasts was modified compared with normal dog osteoblasts or after carprofen treatment in this last study. This observation with the in vivo dog model of OA is different, however,
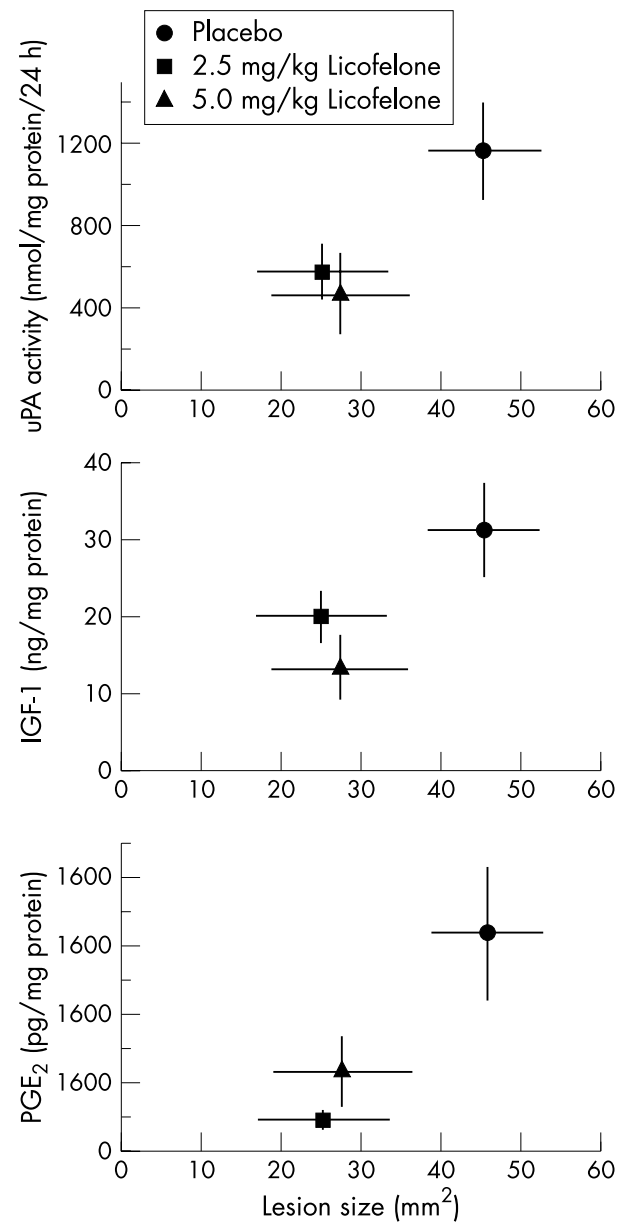

Figure 6 Relationship between the size (surface, $\mathrm{mm}^{2}$ ) of macroscopic lesions on the tibial plateau and UPA activity, IGF-I or PGE 2 levels in dog osteoblasts from dogs treated with placebo or with $2.5 \mathrm{mg} / \mathrm{kg}$ or $5.0 \mathrm{mg} / \mathrm{kg}$ licofelone daily for eight weeks before the preparation of primary osteoblasts. Individual values for UPA activity are derived from fig 3, IGF-I from fig 4, and PGE 2 from fig 5. Values are the mean (SEM) of seven cell cultures for each group. 
from the situation with human OA subchondral osteoblasts, which show increased alkaline phosphatase activity and osteocalcin release compared with normal. ${ }^{45}$ This may be related to the naturally occurring disease state in humans as opposed to its induction in the experimental OA dog model.

In contrast, UPA activity and IGF-I levels were raised in in vitro osteoblasts isolated from this experimental OA dog model. We previously showed similar data for OA dog osteoblasts compared with normal dog osteoblasts, ${ }^{15}$ a situation also similar to that observed in human OA subchondral osteoblasts, indicating that these metabolic modifications are important pathways in disease progression. This is further indicated by the fact that licofelone caused a decrease in both UPA activity and IGF-I levels, reducing them to levels similar to those seen in normal dog osteoblasts. ${ }^{15}$ The effect of licofelone on uPA activity and IGF-I levels may be related to its reduction of $\mathrm{PGE}_{2}$ levels. Indeed, $\mathrm{we}^{39}$ and others ${ }^{40}$ previously showed that $\mathrm{PGE}_{2}$ can regulate IGF-I synthesis in osteoblasts, whereas its effect on uPA activity was never assessed. The observation that the modifications of both UPA and IGF-I follow the inhibition of $\mathrm{PGE}_{2}$ synthesis observed with licofelone suggests a possible link between uPA and $\mathrm{PGE}_{2}$. However, this will have to be tested directly. Abnormal bone remodelling in OA may be linked to altered IGF-I levels in OA bone tissue and osteoblasts, ${ }^{45}$ and its relationship with the uPA/plasmin system..$^{5}$ Indeed, raised IGF-I levels are found in $\mathrm{OA}$ bone tissue even at sites distant from weightbearing joints, ${ }^{21}$ and raised IGF-I levels have been associated with knee OA. ${ }^{41}$

$\mathrm{LTB}_{4}$ levels were very low in dog Ob under the present experimental conditions and licofelone treatment could not modify them. This is probably due to a rapid down regulation of leucotriene synthesis in dog osteoblasts when they are kept in in vitro cell culture as in this study. Hence, it is difficult to assess the long term effect of licofelone on $\mathrm{LTB}_{4}$ production in this in vitro cell model. However, our group previously showed in the experimental OA dog model that licofelone reduced both $\mathrm{PGE}_{2}$ and $\mathrm{LTB}_{4}$ levels in the synovial fluid of these animals. ${ }^{30}$ Moreover, we showed that licofelone reduced both $\mathrm{PGE}_{2}$ and $\mathrm{LTB}_{4}$ levels in human OA subchondral osteoblasts in vitro. ${ }^{23}$ The observation that at the same time as licofelone reduced plateau size and other indicators of $\mathrm{OA}$ progression in vivo ${ }^{30}$ it also reduced uPA activity, IGF-I, and $\mathrm{PGE}_{2}$ levels in in vitro dog $\mathrm{Ob}$ suggests a link between these events. The exact mechanism(s) responsible for this link is presently unknown but most certainly involves the regulation of $\mathrm{PGE}_{2}$ and $\mathrm{LTB}_{4}$ synthesis. Lastly, the absence of effect of licofelone on osteophytes in OA dog knee joints might be linked to the mechanisms responsible for their formation. Increased transforming growth factor $\beta$ (TGF $\beta$ ) levels have been linked with osteophyte formation in animal models of $\mathrm{OA}^{42-44}$ and TGF $\beta$ levels are raised in human subchondral bone tissue explants $^{45}$ and in bone explants from non-weightbearing sites. ${ }^{21}$ As licofelone is a specific inhibitor for 5-LO and COX-I/ COX-II, it may not be able to modulate in vivo TGF $\beta$ levels in dogs with OA, and hence could not directly influence osteophyte formation.

In conclusion, we showed that in vivo treatment with licofelone of experimental dogs with OA exerts a positive effect on a number of the metabolic alterations seen in osteoblasts isolated from these animals. Notwithstanding the long term cell culture time required, licofelone specifically reduced $\mathrm{PGE}_{2}$ levels, which in turn could influence IGF-I levels and, possibly, uPA activity. However, licofelone had no adverse effects on growth or phenotypic expression of dog osteoblasts.

\section{ACKNOWLEDGEMENTS}

Supported in part by a grant from Merckle GmbH, Ulm, Germany and the Fonds de la Recherche en Santé du Québec, Équipe prioritaire en arthrose.

\section{Authors' affiliations}

D Lajeunesse, J Martel-Pelletier, J C Fernandes, J-P Pelletier, Unité de recherche en Arthrose, Centre Hospitalier de l'Université de Montréal, Hôpital Notre-Dame, Montréal, Québec, Canada

S Laufer, Eberhard-Karls-University, Tuebingen, Germany

\section{REFERENCES}

1 Pelletier JP, Martel-Pelletier J, Howell DS. Etiopathogenesis of osteoarthritis. In: Koopman WJ, ed. Arthritis and allied conditions. A textbook of rheumatology. Baltimore: Williams \& Wilkins, 2001:2195-245.

2 Pelletier JP, Martel-Pelletier J, Abramson SB. Osteoarthritis, an inflammatory disease: potential implication for the selection of new therapeutic targets. Arthritis Rheum 2001;44:1237-47.

3 Martel-Pelletier J, Di Battista JA, Lajeunesse D. Biochemical factors in joint articular tissue degradation in osteoarthritis. In: Reginster JY, Pelletier JP, Martel-Pelletier J, Henrotin Y, eds. Osteoarthritis: clinical and experimental aspects. Berlin: Springer, 1999:156-87.

4 Hilal G, Martel-Pelletier J, Pelletier JP, Ranger P, Lajeunesse D. Osteoblast-like cells from human subchondral osteoarthritic bone demonstrate an altered phenotype in vitro: possible role in subchondral bone sclerosis. Arthritis Rheum 1998:41:891-9

5 Hilal G, Martel-Pelletier J, Pelletier JP, Duval N, Lajeunesse D. Abnormal regulation of urokinase plasminogen activator by insulin-like growth factor 1 in human osteoarthritic subchondral osteoblasts. Arthritis Rheum 1999:42:2112-22.

6 Mansell JP, Tarlton JF, Bailey AJ. Biochemical evidence for altered subchondral bone collagen metabolism in osteoarthritis of the hip. Br J Rheumatol 1997;36:16-19.

7 Mansell JP, Bailey AJ. Abnormal cancellous bone collagen metabolism in osteoarthritis. J Clin Invest 1998;101:1596-603.

8 Li B, Aspden RM. Composition and mechanical properties of cancellous bone from the femoral head of patients with osteoporosis or osteoarthritis. J Bone Miner Res 1997; 12:641-51.

9 Li B. Aspden RM. Mechanical and material properties of the subchondral bone plate from the femoral head of patients with osteoarthritis or osteoporosis. Ann Rheum Dis 1997;56:247-54

10 Westacott Cl, Webb GR, Warnock MG, Sims JV, Elson CJ. Alteration of cartilage metabolism by cells from osteoarthritic bone. Arthritis Rheum 1997:40:1282-91.

11 Brandt KD. Insights into the natural history of osteoarthritis provided by the cruciate-deficient dog. An animal model of osteoarthritis [review]. Ann NY Acad Sci 1994:732:199-205.

12 Dedrick DK, Goldstein SA, Brandt KD, O'Connor BL, Goulet RW, Albrecht M. A longitudinal study of subchondral plate and trabecular bone in cruciatedeficient dogs with osteoarthritis followed up for 54 months. Arthritis Rheum 1993;36:1460-7

13 Dedrick DK, Goulet RW, O'Connor BL, Brandt KD. Preliminary report: increased porosity of the subchondral plate in an accelerated canine model of osteoarthritis. Osteoarthritis Cartilage 1997;5:71-4.

14 Brandt KD, Myers SL, Burr D, Albrecht M. Osteoarthritic changes in canine articular cartilage, subchondral bone, and synovium fifty-four months after transection of the anterior cruciate ligament. Arthritis Rheum 1991;34:1560-70

15 Pelletier JP, Lajeunesse D, Jovanovic DV, Lascau-Coman V, Jolicoeur FC Hilal G, et al. Carprofen simultaneously reduces progression of morphological changes in cartilage and subchondral bone in experimental dog osteoarthritis. J Rheumatol 2000;27:2893-902.

16 Bailey AJ, Sims TJ, Knott L. Phenotypic expression of osteoblast collagen in osteoarthritic bone: production of type I homotrimer. Int J Biochem Cell Biol 2002:34:176-82.

17 Carlson CS, Loeser RF, Purser CB, Gardin JF, Jerome CP. Osteoarthritis in cynomolgus macaques. III: Effects of age, gender, and subchondral bone thickness on the severity of disease, J Bone Miner Res 1996;11:1209-17.

18 Hulth A. Does osteoarthrosis depend on growth of the mineralized layer of cartilage? Clin Orthop 1993;287:19-24.

19 Grynpas MD, Alpert B, Katz I, Lieberman I, Pritzker KPH. Subchondral bone in osteoarthritis. Calcif Tissue Int 1991:49:20-6.

20 Radin EL, Rose RM. Role of subchondral bone in the initiation and progression of cartilage damage. Clin Orthop 1986;213:34-40.

21 Dequeker J, Mohan R, Finkelman RD, Aerssens J, Baylink DJ. Generalized osteoarthritis associated with increased insulin-like growth factor types I and II and transforming growth factor beta in cortical bone from the iliac crest. Possible mechanism of increased bone density and protection against osteoporosis. Arthritis Rheum 1993;36:1702-8.

22 Gevers G, Dequeker J. Collagen and non-collagenous protein content (osteocalcin, sialoprotein, proteoglycan) in the iliac crest bone and serum osteocalcin in women with and without hand osteoarthritis. Coll Relat Res 1987;7:435-42.

23 Paredes Y, Massicotte F, Pelletier JP, Martel-Pelletier J, Laufer S, Lajeunesse D. Study of role of leukotriene B4 in abnormal function of human subchondral 
osteoarthritis osteoblasts. Effects of cyclooxygenase and/or 5-lipoxygenase inhibition. Arthritis Rheum 2002;46:1804-12.

24 Massicotte F, Lajeunesse D, Benderdour M, Pelletier J-P, Hilal G, Duval N, et al. Can altered production of interleukin $1 \beta$, interleukin-6, transforming growth factor- $\beta$ and prostaglandin E2 by isolated human subchondral osteoblasts identify two subgroups of osteoarthritic patients. Osteoarthritis Cartilage 2002;10:491-500

25 Imhof $\mathbf{H}$, Breitenseher M, Kainberger F, Rand T, Trattnig S. Importance of subchondral bone to articular cartilage in health and disease. Top Magn Reson Imaging 1999; 10:180-92.

26 Sokoloff L. Microcracks in the calcified layer of articular cartilage. Arch Pathol Lab Med 1993;117:191-5.

27 Mital MA, Millington PF. Osseous pathway of nutrition to articular cartilage of the human femoral head. Lancet 1970; 1:842.

28 Pelletier JP, Jovanovic D, Fernandes JC, Manning PT, Connor JR, Currie MG, et al. Reduced progression of experimental osteoarthritis in vivo by selective inhibition of inducible nitric oxide synthase. Arthritis Rheum 1998:41:1275-86.

29 Pelletier JP, Di Battista JA, Raynauld JP, Wilhelm S, Martel-Pelletier J. The in vivo effects of intraarticular corticosteroid injections on cartilage lesions, stromelysin, interleukin-1 and oncogene protein synthesis in experimental osteoarthritis. Lab Invest 1995;72:578-86.

30 Jovanovic DV, Fernandes JC, Martel-Pelletier J, Jolicoeur FC, Reboul P, Laufer $\mathrm{S}$, et al. The in vivo dual inhibition of cyclooxygenase and lipoxygenase by $\mathrm{ML}-3000$ reduces the progression of experimental osteoarthritis. Suppression of collagenase-1 and interleukin-1 beta synthesis. Arthritis Rheum 2001:44:2320-30.

31 Pelletier JP, Mineau F, Raynauld JP, Woessner JF Jr, Gunja-Smith Z, MartelPelletier J. Intraarticular injections with methylprednisolone acetate reduce osteoarthritic lesions in parallel with chondrocyte stromelysin synthesis in experimental osteoarthritis. Arthritis Rheum 1994;37:414-23.

32 Fernandes JC, Martel-Pelletier J, Otterness IG, Lopez-Anaya A, Mineau F, Tardif $G$, et al. Effects of tenidap on canine experimental osteoarthritis: I. Morphologic and metalloprotease analysis. Arthritis Rheum 1995; 38:1290-303.

33 Lajeunesse D, Busque L, Ménard P, Brunette MG, Bonny Y. Demonstration of an osteoblast defect in two cases of human malignant osteopetrosis: correction of the phenotype after bone marrow transplant. J Clin Invest 1996;98:1835-42.
34 Lajeunesse D, Kiebzak GM, Frondoza C, Sacktor B. Regulation of osteocalcin secretion by human primary bone cells and by the human osteosarcoma cell line MG-63. Bone Mineral 1991;14:237-50.

35 Smith PK, Krohn RI, Hermanson GT, Mallia AK, Gartner FH, Provenzano MD et al. Measurement of protein using bicinchoninic acid. Anal Biochem 1985; 150:76-85.

36 Leprince $\mathbf{P}$, Rogister B, Moonen G. A colorimetric assay for the simultaneous measurement of plasminogen activators and plasminogen activator inhibitors in serum-free conditioned media from cultured cells. Anal Biochem 1989;177:341-6.

37 Mohan S, Bautista CM, Herring SJ, Linkhart TA, Baylink DJ. Development of valid methods to measure insulin-like growth factors-I and -II in bone cellconditioned medium. Endocrinology 1990; 126:2534-42.

38 Gundberg CM, Hauschka PV, Lian JB, Gallop PM. Osteocalcin: isolation, characterization and detection. Methods Enzymol 1984;107:516-44.

39 Massicotte F, Martel-Pelletier J, Pelletier J-P, Lajeunesse D. Abnormal modulation of insulin-like growth factor 1 levels in human osteoarthritic bone oesteoblast (abstract). Arthritis Rheum 2000;43(suppl):S206.

40 McCarthy TL, Centrella M Raisz LG, Canalis E. Prostaglandin E2 stimulates insulin-like growth factor I synthesis in osteoblast-enriched cultures from fetal rat bone. Endocrinology 1991;128:2895-900.

41 Schouten JS, Van den Ouweland FA, Valkenburg HA, Lamberts SW. Insulinlike growth factor-1: a prognostic factor of knee osteoarthritis. $\mathrm{Br} J$ Rheumatol 1993;32:274-80.

42 van Beuningen HM, van der Kraan PM, Arntz OJ, van den Berg WB. Transforming growth factor-beta 1 stimulates articular chondrocyte proteoglycan synthesis and induces osteophyte formation in the murine knee joint. Lab Invest 1994;71:279-90.

43 van den Berg WB. Growth factors in experimental osteoarthritis: transforming growth factor beta pathogenic? J Rheumatol Suppl 1995;43:143-5.

44 van Beuningen HM, Glansbeek HL, van der Kraan PM, van den Berg WB. Differential effects of local application of BMP-2 or TGF-beta 1 on both articular cartilage composition and osteophyte formation. Osteoarthritis Cartilage 1998;6:306-17.

45 Martel-Pelletier J, Hilal G, Pelletier JP, Ranger P, Lajeunesse D. Evidence for increased metabolic activity in human osteoarthritic subchondral bone explants (abstract). Arthritis Rheum 1997;40(suppl):S182. 